\title{
Conceptual Cultivation and Homegrown Theorizing: The Case of/for the Concept of Influence
}

\author{
Eyüp Ersoy
}

\begin{abstract}
The absence of theoretical perspectives in International Relations originating in the worldviews and experiences of human geographies outside the West has elicited persistent calls in the discipline for homegrown theoretical frameworks based on indigenous practices and intellectual sensibilities. Responding to the veritable marginalization of non-Western viewpoints in the discipline belying the plurality of global experiences, a diverse range of studies on homegrown theorizing has ensued. Inasmuch as the initial step in any social theorizing is pertinent to concepts, studies of homegrown theorizing have necessarily engaged conceptual cultivation by drawing on local conceptual resources. Most of these studies, nonetheless, have evinced an analytical proclivity to forge an exclusive and immutable semantic affiliation between concepts and what they signify. Transmuting conceptual indigeneity into conceptional idiosyncrasy, this insular practice of homegrown theorizing can incur manifold degenerative shortcomings. On the other hand, in the lexicon of international relations, influence is a ubiquitous word which is yet to be rigorously conceptualized. By virtue of imparting indigenous properties, a systematic conceptual cultivation of influence is propounded in this study, which arguably transcends the prohibitive semantic inflexibility and associated shortcomings of conceptual exclusivity in homegrown theorizing.
\end{abstract}

Keywords: Conceptual cultivation, homegrown theorizing, influence, power, conceptual exclusivity

\section{Introduction}

Homegrown theorizing in international relations has recently gained more salience in disciplinary debates thanks to persistent calls for theoretical pluralism in international relations. The fundamental rationale underlying such disciplinary appeals is the consequential absence of theoretical perspectives originating in the worldviews and experiences of human geographies outside the West. Peoples of rich diversity in their historical and contemporary practices in international relations are generally relegated to secondary, and even subordinate, analytical categories, such as 'the periphery,' in relation to 'the West,' despite the unmistakable fact that their dispositions, preferences, and actions have been equally significant in the ultimate outcomes of global processes. The majority of the world, called 'the non-West,"

Eyüp Ersoy, PhD, Independent Researcher, International Relations. Email: eyupersoy@hotmail.com.

There are indeed several analytical categories employed in the discipline to identify and differentiate human geographies in international relations with distinct and usually incongruent empirical scopes and normative connotations. One overarching classificatory template is the binary division of the world into two, one category being assigned to what is called 'the West,' and the other category being assigned to 'what-is-not-the-West.' The second category has been called the third world, the global south, the rest, and the developing world, among others. Abiding by the denomination that seems to have achieved widespread recognition in studies of and on homegrown theorizing, in this study 'the non-West' is preferred. 
who are constitutive of the reality that is called international relations are not interpretative of that reality, and are only deemed illustrative for Western theory.

Although a corpus of non-Western theoretical approaches equivalent to that of Western theoretical approaches in composition, sophistication, and progression has yet to emerge in the discipline, a formative recognition of the necessity and feasibility of constructing indigenous perspectives to understand, explain, and predict international phenomena based on local intellectual sensibilities has incrementally suffused disciplinary discussions. Since the initial step in any social theorizing is pertinent to concepts, studies on homegrown theorizing have necessarily encountered the exigency of engaging conceptual inquiries. In this paper, first, the essential role of concepts in homegrown theorizing is discussed, and the varieties of native conceptual resources on which homegrown attempts of conceptual cultivation draw are introduced. In addition, the ways through which conceptual cultivation in homegrown theorizing can be performed are presented. Second, a novel definition of the concept of influence is propounded since a rigorous and systematic conceptual cultivation of influence is still lacking in international relations literature despite its perfunctory extensive usage. Besides, a special analytical emphasis is given to the relationship between influence and power. In the final section, conceptual exclusivity in homegrown theorizing and the analytical shortcomings it creates are critically discussed, and the explanatory potential of the concept of influence in homegrown theorizing is assessed, and affirmed.

\section{Conceptual Cultivation and Homegrown Theorizing}

The indispensability of concepts in theorizing in social sciences arises from the simple methodological necessity that concepts "are some of the main building blocks for constructing theoretical propositions." 2 Concept formation is ontologically crucial in identifying the phenomena and defining their attributes to be theorized. Accordingly, concepts determine the ontological contours of theory construction and the ensuing theoretical analysis by signifying certain phenomena with preconceived properties in social reality by simultaneously excluding some other phenomena or by excluding some other properties of the same phenomena from the process of theory construction. The construction of concepts, on the other hand, is a dynamic process that is subject to innovations, revisions, disputations, and contestations, more often than not susceptible to analytical confusion. ${ }^{3}$ In this study, I prefer 'conceptual cultivation' instead of the more mechanical term of 'concept construction' inasmuch as concepts are like living things embedded in the systems of meaning they are 'planted,' to which they acclimate in constantly transmuting varieties with outcomes ranging from sprouting to flourishing and sometimes to withering, semantically speaking.

As a case of conceptual cultivation in international studies, a passionate theoretical debate on the nature and extent of security persists. Security is an "essentially contested concept,"4 argues Barry Buzan, whereas for David A. Baldwin, "security is more appropriately

\footnotetext{
2 Gary Goertz, Social Science Concepts: A User's Guide (New Jersey: Princeton University Press, 2006), 1. Concurring with Goertz, another scholar adds that "concepts are the building-blocks of all inferences, and the formation of many concepts is clearly, and legitimately, theory-driven." John Gerring, "What Makes a Concept Good? A Critical Framework for Understanding Concept Formation in the Social Sciences," Polity 31 (1999): 364. Emphasis in original.

3 See, for example, Leonidas Tsilipakos, Clarity and Confusion in Social Theory: Taking Concepts Seriously (Surrey: Ashgate Publishing, 2015). For example, in different theoretical fields of international relations, the concept of structure is attributed distinct meanings. Even in the sub-fields of the same theory, structure would have come to assume very different meanings. Accordingly, in the absence of sedulous assessment, analytical confusion is bound to ensue.

4 Barry Buzan, People, States, and Fear: The National Security Problem in International Relations (Sussex: Wheatsheaf Books, 1983), 6.
} 
described as a confused or inadequately explicated concept than as an essentially contested one." Essentially complicated or not, security is a cultivated concept in international relations. Depending on the referent object of security, or the unit of analysis, the scope of security research has been explored from 'rice security' to 'space security.' It has also been 'cultivated' at different levels of analysis: encompassing human/individual security, societal security, state/national security, regional security, international security, and global/world security. ${ }^{6}$ Among the conceptual derivations of security eliciting extensive analytical interest is ontological security, which refers "to the need to experience oneself as a whole, continuous person in time-as being rather than constantly changing-in order to realize a sense of agency." " Another derivative concept constituting the basis of an influential school in security studies, i.e. the Copenhagen School, is securitization. ${ }^{8}$ In brief, conceptual cultivation of security has proved to constitute a fertile research agenda in international relations.

Conceptual cultivation in theoretical studies in pursuit of devising indigenous analytical frames of reference is preceded, as it seems, by a self-reflexive process of exploring and exploiting native conceptual resources. ${ }^{9}$ Among conceptual resources, first, the notions and convictions of classical thinkers in non-Western contexts are revisited, reinterpreted, and reconfigured to develop indigenous approaches to international relations. This reflects a similar formative trajectory in the emergence of Western IR theory, which claims to represent an intellectual pedigree originating in the works of historical figures from Thucydides onwards. In the Chinese context, for example, the ideas of Sun Tzu and Confucius are recurrent themes of studies on homegrown approaches, while in the Indian context, the views of Kautilya, also called Chanakya, are habitually drawn upon. ${ }^{10}$ Second, historical traditions of thought, beliefs, and conventions are invoked instead of particular sages or scholars. Accordingly, for instance, Confucianism instead of Confucius, and Islamic thought instead of Ibn Khaldun are appropriated as conceptual resources. ${ }^{11}$ Historical experiences of non-Western peoples and

5 David A. Baldwin, "The Concept of Security," Review of International Studies 23, no. 1 (1997): 12. Also see, Benjamin Miller, "The Concept of Security: Should it be Redefined?" Journal of Strategic Studies 24, no. 2 (2001): 13-42.

6 For some examples, see, Amy Freedman, "Rice Security in Southeast Asia: Beggar Thy Neighbor or Cooperation," The Pacific Review 26, no. 5 (2013): 433-54; Kai-Uwe Schrogl et al., eds., Handbook of Space Security: Policies, Applications and Programs (New York: Springer, 2015); Shahrbanou Tadjbakhsh and Anuradha Chenoy, Human Security: Concepts and Implications (Oxon: Routledge, 2007); Paul Roe, Ethnic Violence and the Societal Security Dilemma (Oxon: Routledge, 2005); Norrin M. Ripsman and T. V. Paul, Globalization and the National Security State (New York: Oxford University Press, 2010); Thomas G. Mahnken and Dan Blumenthal, eds., Strategy in Asia: The Past, Present, and Future of Regional Security (Stanford: Stanford University Press, 2014); Karin M. Fierke, Critical Approaches to International Security (Cambridge: Polity Press, 2015); Ken Booth, Theory of World Security (Cambridge: Cambridge University Press, 2007).

Jennifer Mitzen, "Ontological Security in World Politics: State Identity and the Security Dilemma," European Journal of International Relations 12, no. 3 (2006): 342. It is asserted, for example, that "while physical security is (obviously) important to states, ontological security is more important because its fulfillment affirms a state's self-identity (i.e. it affirms not only its physical existence but primarily how a state sees itself and secondarily how it wants to be seen by others)," and furthermore, "nation-states seek ontological security because they want to maintain consistent self-concepts, and the 'Self' of states is constituted and maintained through a narrative which gives life to routinized foreign policy actions." Brent J. Steele, Ontological Security in International Relations: Self-Identity and the IR State (Oxon: Routledge, 2008), 2-3. For an application of ontological security in a non-Western context see, Catarina Kinnvall, Globalization and Religious Nationalism in India: The Search for Ontological Security (Oxon: Routledge, 2006).

8 For a recent application of securitization in a non-Western context see, Mely Caballero-Anthony, Ralf Emmers and Amitav Acharya, eds., Non-Traditional Security in Asia: Dilemmas in Securitisation (Oxon: Routledge, 2016).

9 For example, Aydınlı and Mathews suggest that homegrown theorizing "address an existing body of literature, but [find] a gap or inconsistency in that literature and then [add] to that existing literature with concepts derived out of the local context and case." Ersel Aydınlı and Julie Mathews, "Periphery Theorising for a Truly Internationalised Discipline: Spinning IR Theory out of Anatolia," Review of International Studies 34 (2008): 702.

10 For some examples, see, Yan Xuetong, "Xun Zi's [Sun Tzu] Thoughts on International Politics and Their Implications," Chinese Journal of International Politics 2, no. 1 (2008): 135-65; Yan Xuetong, Ancient Chinese Thought, Modern Chinese Power (New Jersey: Princeton University Press, 2011); P. K. Gautam, "Relevance of Kautilya's Arhasastra," Strategic Analysis 37, no. 1 (2013): 21-8.

11 See, among others, Cho-yun Yuan-Kang Wang, Harmony and War: Confucian Culture and Chinese Power Politics (New 
polities are reflected upon to reveal authentic modes of thought and action in international relations. ${ }^{12}$ There can be other conceptual resources of equal analytical import in homegrown theorizing, such as foundational civilizational/cultural texts, foreign policy doctrines of political leaders, and contemporary state of affairs in international relations. ${ }^{13}$

In conceptual cultivation, what is of consequence is not the morphology of a concept but its semantics. For instance, referring to the concept of influence as nufü $/$ / nofooz (transliterations of the same word نفو in Arabic and Persian respectively) in an Arabic, Iranian, or in general, Islamic context does not spontaneously impart indigeneity to the concept. The semantic criteria for the indigeneity of influence in these contexts is its peculiar meanings with authentic connotations. Drawing on local conceptual resources, conceptual cultivation for homegrown theorizing can be performed in five distinct ways. ${ }^{14}$ First, a researcher can engage in novel conceptualization by appropriating a common linguistic unit, be it a word or a phrase, and attributing idiosyncratic properties to it, effectively rendering the word or phrase into a concept. Security is a common word employed in everyday language, and yet with the ascription of unique qualities, it is translated into a concept in international studies through a myriad of conceptualizations. These qualities, nonetheless, may not be necessarily derived from already existing indigenous conceptual resources inasmuch as these qualities constitute indigenous qualities in and of themselves as parts of the novel conceptualization.

Second, a researcher can redefine a concept already in use in Western theorizing by virtue of imparting indigenous properties to it. For example, one can reconceptualize human security by reconfiguring its referents as belief/religion, life, wealth/property, procreation/offspring, and mind/intellect from an Islamic perspective, the protection and preservation of which is considered the ultimate purpose of Islamic jurisprudence. Third, a researcher can take a non-conceptual derivative of a concept, which is again already in use in Western theorizing, usually in its adjectival form or phrasal alteration, and attribute indigenous characteristics to it. In Western theorizing, securitization and human security are two foremost examples, and the same approach is equally valid, at least in theory, for non-Western theorizing. Fourth, a researcher can opt for an indigenous concept, and apply it to theoretical undertaking in its authentic sense or senses (a concept in a sophisticated tradition of thought can acquire multiple meanings in the process of intellectual speculation). Harmony is a cultivated concept in Chinese political philosophy, and its referral in its original sense(s) in studies of China's international relations is, for the most part, a preference to establish a coherent conceptual framework for indigenous theoretical approaches. Fifth, on the other hand, revising its

York: Columbia University Press, 2011); Feng Zhang, "Confucian Foreign Policy Traditions in Chinese History," The Chinese Journal of International Politics 8, no. 2 (2015): 197-218; Deina Abdelkader, Nassef Manabilang Adiong and Raffaele Mauriello, eds., Islam and International Relations: Contributions to Theory and Practice (Hampshire: Palgrave Macmillan, 2016); Jack Kalpakian, "Ibn Khaldun's Influence on Current International Relations Theory," The Journal of North African Studies 13, no. 3 (2008): 363-76.

12 See, for example, Victoria Tin-bor Hui, War and State Formation in Ancient China and Early Modern Europe (Cambridge: Cambridge University Press, 2005); David C. Kang, "Hierarchy and Legitimacy in International Systems: The Tribute System in Early Modern East Asia," Security Studies 19, no. 4 (2010): 591-622.

${ }_{13}$ In terms of homegrown theorizing in India, see, for example, Kautilya, The Arthashastra (New Delhi: Penguin Books, 1992); Aspy P. Rana, The Imperatives of Nonalignment: A Conceptual Study of India's Foreign Policy Strategy in the Nehru Period (Delhi: Macmillan, 1976); Sreeram S. Chaulia, "BJP, India's Foreign Policy and the 'Realist Alternative' to the Nehruvian Tradition," International Politics 39, no. 2 (2002): 215-34.

14 The following discussion draws, in part, on Gonca Biltekin, "Özgün teori inşası ve batı-dışı uluslararası ilişkiler teorileri [Homegrown theorizing and non-western international relations theories], " in Uluslararast ilişkiler teorileri [International relations theories], ed. Ramazan Gözen (İstanbul: İletişim Yayınc1lık, 2014), 517-64. 
authentic sense(s), a researcher can redefine an indigenous concept for analytical purposes, such as its application in a different level of analysis or its application to a different unit of analysis.

\section{Conceptual Cultivation of Influence}

In the lexicon of the discipline of international relations, influence is a ubiquitous word which is yet to be rigorously conceptualized, and it is a phenomenon in international politics which is yet to be extensively theorized. This is a curious disciplinary case for some reasons. First, 'sphere of influence' as a phrase has been in use in the academic literature since it was first coined at the Berlin Conference (1884-1885), which divided the African continent into the 'spheres of influences' of European colonial powers. ${ }^{15}$ In other words, it is not a novel conceptual innovation nor is it recently incorporated into the discipline of international relations from other disciplines. Second, concepts similarly in use in the international relations literature like power and security have been excessively studied in the discipline both theoretically and empirically to the extent that these studies have constituted separate literatures of their own. ${ }^{16}$ Third, influence as an uncultivated concept has been extensively employed in academic as well as non-academic studies becoming an inseparable part of the international relations literature. In most of these studies, however, there appears to be no attempt to formulate and clarify the concept of influence, that is, no attempt for conceptualization, and the meaning of influence is just assumed as self-evident, or the author's understanding of the concept of influence is implicit within the text and can only be inferred indirectly from the text.

Therefore, with regard to influence, there seems to be a conceptual and theoretical underdevelopment in international relations literature, which requires, above all, a systematic and yet lucid conceptual cultivation of influence. On the other hand, influence, as a phenomenon, is inherently related to power in international relations, and is frequently confused with it. Accordingly, introducing a distinct definition of influence necessitates differentiating the two concepts. Hence, power needs to be clarified first.

"Power, like love, is easier to experience than to define or measure," Joseph S. Nye, Jr. poetically acknowledges. ${ }^{17}$ Nonetheless, the enticing challenge of defining or measuring power, like love, has been embraced by scholars of international relations with ardor. Scholars of international relations have depended on divergent conceptions of power in their analyses, and there has yet to be a consensus on a common definition. These diverse conceptions of power have frequently challenged, contradicted, complemented, and overlapped each other. It is no surprise that the simple linguistic characteristics that two ontologically distinct entities can be signified by the same concept is lost in the exhaustive conceptual debates on power. Power is a polysemous word essentially signifying two ontologically discrete phenomena, and thus having two distinct meanings. There have been attempts to define these two discrete phenomena with two different concepts. One early attempt came from Raymond Aron, who

15 Asa Briggs and Patricia Clavin, Modern Europe, 1789-Present (Oxon: Routledge, 2013), 129. Also see, Lloyd C. Gardner, Spheres of Influence: The Great Powers Partition Europe, from Munich to Yalta (Chicago: Ivan R. Dee, 1993); Susanna Hast, Spheres of Influence in International Relations: History, Theory and Politics (Surrey: Ashgate, 2014).

16 There is now 'security studies' as a sub-discipline in international relations, involving conceptual and substantial analyses of security. See, for example, Barry Buzan and Lene Hansen, The Evolution of International Security Studies (Cambridge: Cambridge University Press, 2009); Paul D. Williams, ed., Security Studies: An Introduction (Oxon: Routledge, 2013); Alan Collins, ed., Contemporary Security Studies (Oxford: Oxford University Press, 2013); Peter Hough et al., eds., International Security Studies: Theory and Practice (Oxon: Routledge, 2015).

17 Joseph S. Nye Jr., Power in the Global Information Age: From Realism to Globalization (Oxon: Routledge, 2004), 53. 
pointed out that "French, English and German all distinguish between two notions, power and force (strength), puissance et force, Macht und Kraft," analogous to the Turkish notions of kudret and kuvvet. ${ }^{18}$ To Aron, it did not seem "contrary to the spirit of these languages to reserve the first term for the human relationship, the action itself, and the second for the means, the individual's muscles or the state's weapons." 19 A similar dichotomy has recently emerged distinguishing between the action itself and the means with the concepts of 'power-over' and 'power-to,' though the precise and unanimous definitions of 'power-over' and 'power-to' have yet to be agreed upon among scholars. ${ }^{20}$ Even so, two conceptions of power, one pertinent to the means of interaction, and the other pertinent to the outcome of interaction, are discernable.

The first conception of power, which can be called 'power as capacity' (Power I), refers to the material and non-material, tangible and intangible, resources possessed, and employed if need be, by an actor to have an effect on the outcome of a process of interaction. This conception of power is espoused, for instance, by John J. Mearsheimer. According to Mearsheimer, while others "define power in terms of the outcomes of the interactions between states," by asserting that power "is all about control or influence over other states," for him power "represents nothing more than specific assets or material resources that are available to a state." ${ }^{21}$ The second conception of power, on the other hand, which can be called 'power as capability' (Power II), refers to the ability of an actor to have an effect on the behavioral outcome of a process of interaction. Accordingly, while power as capacity can be ascertained at any point, in and before a process of interaction, power as capability can only be ascertained at the end of a process of interaction. Although most conceptions of power appraise power as a capability, they differ on the causal mechanism through which certain resources possessed by a state are translated into the ability of state to have an effect on the behavioral outcome of an interaction. I argue that the nexus translating 'power as capacity' (Power I) into 'power as capability' (Power II) is influence.

In the scholarly literature of international relations, influence is in widespread circulation, employed to denote various international phenomena ranging from the international 'influence of potato' to 'influence warfare' between terrorists and governments. ${ }^{22}$ It may refer to policy behaviors of various actors ranging from single personalities to international organizations. ${ }^{23}$ In most of the research, influence is employed in the basic senses of effect or control, in a similar fashion Kenneth N. Waltz observes regarding the concept of 'reification'. He argues that such "loose use of language or the employment of metaphor" serves limited in original.

18 Raymond Aron, Peace and War: A Theory of International Relations (New York: Frederick A. Praeger, 1968), 48. Emphasis

19 Aron, Peace and War, 48.

20 Keith Dowding, ed., Encyclopedia of Power (California: SAGE, 2011), 521-4. Also see, Pamela Pansardi, "Power to and Power over: Two Distinct Concepts of Power," Journal of Political Power 5, no. 1 (2012): 73-89.

21 John J. Mearsheimer, The Tragedy of Great Power Politics (New York: W. W. Norton \& Company, 2001 ), 57.

22 Redcliffe Salaman, The History and Social Influence of the Potato (Cambridge: Cambridge University Press, 1985); James J. F. Forest, ed., Influence Warfare: How Terrorists and Governments Fight to Shape Perceptions in a War of Ideas (Westport: Praeger Security International, 2009).

${ }_{23}$ See, for example, Joas Wagemakers, A Quietist Jihadi: The Ideology and Influence of Abu Muhammad al-Maqdisi (New York: Cambridge University Press, 2012); Jeffrey H. Norwitz, ed., Pirates, Terrorists, and Warlords: The History, Influence, and Future of Armed Groups around the World (New York: Skyhorse Publishing, 2009); Robert I. Rotberg, ed., China into Africa: Trade, Aid, and Influence (Baltimore: Brookings Institution Press, 2008); Alex Warleigh and Jenny Fairbrass, eds., Influence and Interests in the European Union: The New Politics of Persuasion and Advocacy (London: Europa Publications, 2002); Astrid Boening et al., eds., Global Power Europe-Vol. 2: Policies, Actions, and Influence of the EU's External Relations (Heidelberg: Springer, 2013); James Raymond Vreeland and Axel Dreher, The Political Economy of the United Nations Security Council: Money and Influence (New 
purpose other than "to make one's prose more pleasing". ${ }^{24}$ In some other research, however the author's understanding of influence is implicit within the text, and can only be inferred indirectly from the text.

The word 'influence,' coming from Latin means 'flowing into,' akin to its Turkish translation nüfuz, which, coming from Arabic, means 'penetration.' There are tentative definitions, or at least definitional attempts, for influence in international relations literature. An ambiguous definition, for example, was introduced by Frederick H. Hartmann according to whom influence was simply "unconscious power." 25 To Hartmann, "in a more formal sense, power is the strength or capacity that a sovereign nation-state can use to achieve its national interests," and "the very existence of power has an effect," meaning that "no state can ignore the possibility that the power of another state will be used." ${ }^{26}$ Accordingly, he clarifies, "the power of that other state is in effect used, and plays some part both in the initial formulation of policies and in the subsequent relations of the states concerned, even where it is not intentionally put to use." ${ }^{27}$ In short, influence, as unconscious power, ensues. Paul R. Viotti and Mark V. Kauppi, on the other hand, provide a circular definition of influence. They argue that "a state's influence (or capacity to influence or coerce) is not only determined by its capabilities (or relative capabilities) but also by (1) its willingness (and perceptions by other states of its willingness) to use these capabilities and (2) its control or influence over other states. ${ }^{" 28}$ This oblique definition of influence, it seems, confuses more than it clarifies. ${ }^{29}$

A study on regional security strategies in Southeast Asia introduces a novel concept, 'balance of influence,' based on a conception of influence as encapsulating "a range of other modes and means [than military and economic resources] by which states with relatively less preponderance of power may still wield the resources and capacity to shape their strategic circumstances by virtue of status, membership, normative standing, or other persuasive abilities." ${ }^{30}$ According to Evelyn Goh, the conception of 'balance of influence' permits researchers "to expand the number of key reference points from which they may compare resources, and highlights that a state's influence and power may come as much from ideational sources as from material sources. ${ }^{31}$ Goh's conceptualization treats influence as a derivative of non-material instruments and sources of interstate diplomacy. Another study defines influence in a footnote as "power as control over actors," 32 and then refers to Jeffrey Hart's definition of control over actors, i.e. "the ability of A to get B to do something which he would otherwise not do." ${ }^{33}$ This definition of power was originally Dahl's definition of power. ${ }^{34}$ The author acknowledges this definition as the standard definition of power, as

\footnotetext{
${ }^{24}$ Kenneth N. Waltz, Theory of International Politics (Long Grove: Waveland Press, 2010), 120.

${ }^{25}$ Frederick H. Hartmann, The Relations of Nations (New York: The Macmillan Company, 1969), 43.

${ }^{26}$ Hartmann, The Relations of Nations, 41.

27 Hartmann, The Relations of Nations, 41.

${ }_{28}$ Paul R. Viotti and Mark V. Kauppi, International Relations Theory: Realism, Pluralism, Globalism, and Beyond (Needham Heights: Allyn \& Bacon, 1999), 64. Italics added.

${ }^{29}$ The confusion here is the authors' circular assertion that a state's influence is determined by its influence!

${ }_{30}$ Evelyn Goh, "Great Powers and Hierarchical Order in Southeast Asia: Analyzing Regional Security Strategies," International Security 32, no. 3 (2007-08): 147. This is an example of the third way of conceptual cultivation, that is, taking a non-conceptual derivative of a concept in use in Western theorizing, and attribute indigenous characteristics to it in phrasal alteration.

31 Goh, "Great Powers".

32 Jeremy Pressman, "Power without Influence: The Bush Administration's Foreign Policy Failure in the Middle East," International Security 33, no. 4 (2009): 149-79.

33 Jeffrey Hart, "Three Approaches to the Measurement of Power in International Relations," International Organization 30, no. 2 (1976): 291.

${ }^{34}$ Dahl, "The Concept of Power," 202-03.
} 
evident in the works of David A. Baldwin ${ }^{35}$ and Nye, $\mathrm{Jr}^{36}$ Although these scholars regard it as a definition of power, not influence or control, he argues that "this [definition] lumps together two related but distinct elements. ${ }^{37}$ Ironically, in his attempt to define influence as a distinct element, he concludes by subsuming influence with power under the same definition.

As a final example, in his entry of Influence to the Encyclopedia of Power, Keith Dowding indicates two different definitions of influence. In the first definition, influence "is usually considered a form of verbal persuasion," in the sense that "information given by A to B will change B's decision. That information influences B's decision." 38 Here, influence is considered a subset of power. In the second, influence is defined as "the socially induced modification of behavior" and thus, distinct from power, i.e. "structurally determined abilities to change behavior." 39 According to Dowding, "such a demarcation between power and influence is only definitional," and "whether influence is a subset of power or a different category altogether is only of any interest if the difference has any effect on the manner in which we examine and explain society. ${ }^{\circ 4}$ This rather equivocal and evasive evaluation of the distinction between two concepts is unfortunate since it fails to deliver any conceptual clarity between influence and power.

Despite its extensive usage in scholarly studies in international relations, a systematic conceptualization of influence presenting a perspicuous definition of influence and a coherent exposition of its relationship with power is arguably still underdeveloped in the literature. ${ }^{41} \mathrm{In}$ this paper, I am proposing that influence can be defined as the effect of actor A (henceforth A) over the decision of actor B (henceforth B) through A's involvement in the decisionmaking process of $\mathrm{B}$. Therefore, influence is not a cause; it is an effect. In addition, it is not a potentiality; it is an actuality. A has influence over B insofar as the decision of B reflects the preference of A that would otherwise not been reflected. This definition of influence depends on a basic assumption that a state's foreign policy behavior is not a necessary outcome of a state's automatic response to external stimuli. More importantly, a state's foreign policy is assumed to be invariably a contingent outcome of a decision-making process which is susceptible to involvement of other states and actors in different degrees, ways, and forms.

The pervasive confusion in understanding and explaining power, influence, and the relationship between the two originates in the conflation of their points of reference. While power can be about both decision and behavior depending on its type (Power I or Power II), influence is exclusively about decision. This conceptual ambiguity can be noticed, for example, in Thomas C. Schelling's discussion of forcible action. According to Schelling, "the only purpose [of inflicting suffering], unless sport or revenge, must be to influence somebody's behavior, to coerce his decision or choice." ${ }^{\prime 42}$ For Schelling, as it seems, altering the behavior of somebody and altering the decision of somebody are identical. However,

35 David A. Baldwin, "Power Analysis and World Politics: New Trends versus Old Tendencies," World Politics 31 , no. 2 (1979): 161-94.

36 Joseph S. Nye, Jr., The Paradox of American Power: Why the World's Only Superpower Can't Go it Alone (New York: Oxford University Press, 2002).

37 Jeremy Pressman, "Power without Influence: The Bush Administration's Foreign Policy Failure in the Middle East," 150. The quotation is from the footnote.

38 Dowding, Encyclopedia of Power, 342.

39 Dowding, Encyclopedia of Power, 342.

40 Dowding, Encyclopedia of Power, 342.

${ }_{41}$ As a matter of fact, some noteworthy attempts to that end have been made from the perspective of sociology and political science. For a detailed presentation of these studies, see Ruth Zimmerling, Influence and Power: Variations on a Messy Theme (Dordrecht: Springer, 2005).

42 Thomas C. Schelling, Arms and Influence (New Haven: Yale University Press, 2008), 2. 
the act of taking a decision and the act of taking an action, even when it is based on that decision, are two ontologically distinct acts despite being temporally sequential. Taking a decision, let's say, to drink water and taking an action of drinking water are two separate personal acts. By the same token, taking a decision to invade a country and taking an action of invading a country are two separate international acts. ${ }^{43}$ Simply, deciding to do something is one thing while doing that thing is another. Since there is always a processual mechanism through which a decision is or is not translated into an action, the underlying assumption of most conceptions of power that there is a spontaneous translation of decision into behavior is empirically erroneous. Needless to say, enacting a decision, and thereby translating it into behavior is contingent upon a multitude of factors. ${ }^{44}$

Nevertheless, the concurrent use of the concepts of influence and power in a great many studies evinces the general understanding of the inherent association between them. Most of the studies use power and influence conjointly, ${ }^{45}$ some talk of 'power without influence, ${ }^{, 46}$ some talk of 'influence without power, ${ }^{47}$ and some talk of 'influence of power.' ${ }^{48}$ This inherent association in the form of a process connecting power as capacity (Power I), influence, and power as capability (Power II) can be formulated in a simple fashion.

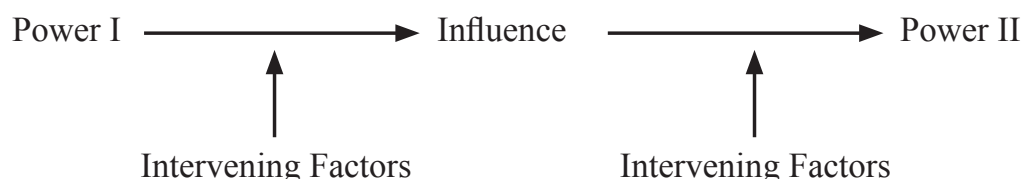

Figure 1: The Nexus between Power I, Influence, and Power II

Power I, as mentioned before, refers to the material and non-material, tangible and intangible, resources possessed and employed by A to have an effect on the behavioral outcome of a process of interaction with B by means of having an effect on the decision of B. While the ultimate objective of A exercising Power I is to have an effect on the behavior

43 See, for example, Michael J. Sullivan III, American Adventurism Abroad: 30 Invasions, Interventions, and Regime Changes since World War II (Westport: Praeger, 2004); Bradley F. Podliska, Acting Alone: A Scientific Study of American Hegemony and Unilateral Use-of-Force Decision Making (Plymouth: Lexington Books, 2010); Ahmed Ijaz Malik, US Foreign Policy and the Gulf Wars: Decision Making and International Relations (London: I. B. Tauris, 2015).

44 In terms of underbalancing, see, for example, Randall L. Schweller, Unanswered Threats: Political Constraints on the Balance of Power (New Jersey: Princeton University Press, 2008).

45 See, for example, Dimitrios G. Kousoulas, Power and Influence: An Introduction to International Relations (Monterey: Wadsworth Publishing, 1985); John M. Rothgeb, Defining Power: Influence \& Force in the Contemporary International System (New York: St. Martin's Press, 1993); Juliet Kaarbo, "Power and Influence in Foreign Policy Decision Making: The Role of Junior Coalition Partners in German and Israeli Foreign Policy," International Studies Quarterly 40, no. 4 (1996): 501-30; Ann L. Phillips, Power and Influence after the Cold War: Germany in East Central Europe (Lanham: Rowman and Littlefield, 2000); Robert E. Hunter, Integrating Instruments of Power and Influence: Lessons Learned and Best Practices (Santa Monica: RAND, 2008); Deborah E. de Lange, Power and Influence: The Embeddedness of Nations (New York: Palgrave Macmillan, 2010); Tore T. Petersen, Anglo-American Policy toward the Persian Gulf, 1978-1985: Power, Influence, and Restraint (Eastbourne: Sussex University Press, 2015); Lorenzo Kamel, Imperial Perceptions of Palestine: British Influence and Power in Late Ottoman Times (New York: I. B. Tauris, 2015).

46 See, for example, Tuomas Forsberg and Antti Seppo, "Power without Influence? The EU and Trade Disputed with Russia," Europe-Asia Studies 61, no. 10 (2009): 1805-23.

47 See, for example, Donald M. Mckale, "Influence without Power: The Last Khedive of Egypt and the Great Powers, 19141918," Middle Eastern Studies 33, no. 1 (1997): 20-39; Carr Ungerer, “Influence without Power: Middle Powers and Arms Control Diplomacy during the Cold War," Diplomacy and Statecraft 18, no. 2 (2007): 393-414.

48 See, for example, Alfred Thayer Mahan, Influence of Sea Power upon History, 1660-1783 (Boston: Little, Brown and Co., 1918); Rick Fawn, "Alliance Behavior, the Absentee Liberator and the Influence of Soft Power: Post-communist State Positions over the Iraq War in 2003," Cambridge Review of International Relations 19, no. 3 (2006): 465-80; Alice V. Monroe, ed., China's Foreign Policy and Soft Power Influence (New York: Nova Science Publishers, 2010). 
of $\mathrm{B}$, the proximate objective of A exercising Power I is to have an effect on the decision of B. The mere act of exercising Power I does not necessarily culminate in producing an effect on the decision of $\mathrm{B}$ due to intervening factors that condition the translation of Power I into an effect on the decision of B.

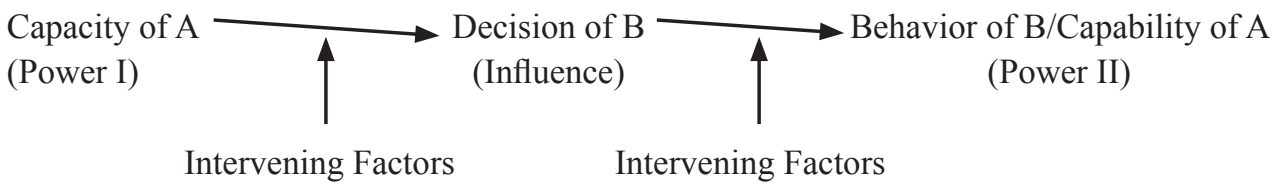

Figure 2: Transition Mechanism from Power I to Influence to Power II

Influence, as mentioned before, is the effect of A over the decision of B through A's involvement in the decisionmaking process of B by virtue of exercising Power I. Accordingly, in verbal form, to influence means to have an effect on the decision of B by virtue of exercising Power I. In adjectival form, being influential means having an effect on the decision of B by virtue of exercising Power I. It is imperative to distinguish between influence act and influential act here. Influence act is a volitional act with whose exercise an effect on the decision of $\mathrm{B}$ is intended. On the other hand, influential act is a volitional act with whose exercise an effect on the decision of B is achieved. Another significant point to stress here is that both A and B are willful agents in possession of the essential attribute of agency, that is, the capacity of making a decision. Accordingly, in this sense, non-willful, that is, non-selfconscious, entities cannot be a party to an influence relationship, neither as a subject nor as an object. Both A and B are necessarily willful agents.

Power II, as mentioned before, refers to the ability of A to have an effect on the behavioral outcome of a process of interaction with B by means of having an effect on the decision of B. There are two highly significant points that need articulation. The first is the relationship between influence and Power II. Influence as the effect of A on the decision of B is not the cause of Power II as the ability of A to have an effect on the behavior of B. There is not a causal relationship between the two as Figure 1 would suggest. Influence and Power II are ontologically distinct and yet require each other to exist; they are like the two sides of the coin. Only with influence can Power II come into existence, and Power II exists as long as influence exists. The second is that influence is a necessary condition for Power II, but not a sufficient condition. For Power II to exist, influence must exist in advance; still, the prior existence of influence does not necessarily lead to Power II. In other words, the effect on the decision of B (influence) does not necessarily lead to an effect on the behavior of B (Power II) due to intervening factors that condition the translation of decisional effect (influence) into behavioral effect (Power II). The respective points of reference for Power I, influence, and Power II are shown below.

$\begin{array}{ll}\text { Power I } & \text { Resources } \\ \text { Influence } & \text { Decision } \\ \text { Power II } & \text { Behavior }\end{array}$

List 1: Points of Reference for Power I, Influence, and Power II 


\section{Influence and Homegrown Theorizing}

An empowered disciplinary unanimity has emerged in international relations on the Westcentric, and specifically Eurocentric, disposition of prevailing theorizing. It is argued, for example, that "the bald fact of Western dominance" is beyond controversy in the established IR theory which manifests itself in "two obvious, and partly reciprocal, ways." Implicitly relating to the questions of epistemology and ontology in theorizing, the first, the scholars continue, "is the origin of most mainstream IRT in Western philosophy, political theory and/ or history. The second is the Eurocentric framing of world history, which weaves through and around much of this theory." ${ }^{50}$ Epistemological privileging of Western modes of knowledge production entrenches cognitive patterns postulating Western superiority in both the theory and practice of international relations. This privilege treatment is trenchantly criticized from several viewpoints. Mohammed Ayoob, for instance, contends that in the discipline "power translates into domination in the sphere of the manufacturing and reproduction of knowledge. Domination in the arena of knowledge further legitimatizes inequality in the international system." ${ }^{\prime 51}$ In terms of the ontological foundations of West-centrism/Eurocentrism of IR theory, the defiant conviction is that "theories about the structures, processes, and events that define and recur within the international realm are based to a large extent on the history of the European states system and its role in world affairs since the sixteenth century." 52 As a result of this exclusive entitlement of Western epistemology and ontology for 'conceivable' theorizing in international relations, the discipline is now considered predominantly hegemonic. ${ }^{53}$

In order to challenge, transform, and transcend the hegemony of the West in IR theorizing, persistent calls with numerous propositions are put forward. It is suggested, for example, that greater attention be paid "to the genealogy of international systems, the diversity of regionalisms and regional worlds, the integration of area studies with IR, people-centric approaches to IR, security and development, and the agency role of non-Western ideas and actors in building global order." ${ }^{54}$ In a similar vein, arguing that the discipline of international relations is "dominated by Western modernity that is premised upon a self-other binary in which the other's identity must be negated and agency be denied," another scholar calls for the decolonization of IR theory for a "democratic ontology." 55 Another strand of research

49 Amitav Acharya and Barry Buzan, "Why is There No Non-Western International Relations Theory? An Introduction," in Non-Western International Relations Theory: Perspectives on and beyond Asia, ed. Amitav Acharya and Barry Buzan (Oxon: Routledge, 2010), 6. Nonetheless, there are some studies contending that the discipline of international relations is not wholly dominated by the US, if not by the West. See, for example, Helen Louise Turton, International Relations and American Dominance: A Diverse Discipline (Oxon: Routledge, 2016).

50 Acharya and Buzan, "Why is There No Non-Western International Relations Theory?," 6.

51 Muhammed Ayoob, "Inequality and Theorizing in International Relations: The Case for Subaltern Realism," International Studies Review 4, no. 3 (2002): 27. Also see, Navid Pourmokhtari, "A Postcolonial Critique of State Sovereignty in IR: The Contradictory Legacy of a 'West-centric' Discipline," Third World Quarterly 34, no. 10 (2013): 1767-93. It is further asserted that even several critical IR theorists, despite being so much critical of the West, ascribe to West-centrism in a form of "subliminal Eurocentrism" as "their analyses are for the White West and for Western Imperialism in various senses." John M. Hobson, "Is Critical Theory Always for the White West and for Western Imperialism? Beyond Westphalian towards a Post-racist Critical IR," Review of International Studies 33 (2007): 93. Emphasis in original.

52 Sandra Halperin, "International Relations Theory and the Hegemony of Western Conceptions of Modernity," in Decolonizing International Relations, ed. Branwen Gruffydd Jones (Maryland: Rowman \& Littlefield Publishers, 2006), 43. Also see, Turan Kayaoglu, "Westphalian Eurocentrism in International Relations Theory,” International Studies Review 12 (2010): $193-217$.

53 For one example, Arlene B. Tickner calls the discipline as having a (neo)imperialist structure. See, Arlene B. Tickner, "Core, Periphery and (Neo)Imperialist International Relations," European Journal of International Relations 19, no. 3 (2013): 627-46. For a more condemning study, see, Errol A. Henderson, "Hidden in Plain Sight: Racism in International Relations Theory," Cambridge Review of International Relations 26, no. 1 (2013): 71-92.

54 Amitav Acharya, "Dialogue and Discovery: In Search of International Relations Theories beyond the West," Millennium: Journal of International Studies 39, no. 3 (2011): 619.

55 Ching-Chang Chen, "The Absence of Non-Western IR Theory in Asia Reconsidered," International Relations of the Asia- 
with an avowed interest in promoting homegrown theorizing has concomitantly focused on the state of the discipline periodically reviewing theoretical developments in non-Western contexts, as well as in the West for purposes of comparison. ${ }^{56}$ Indeed, a diverse array of studies advancing homegrown theoretical perspectives that are predicated on conceptual cultivations appropriating indigenous conceptual resources have been proffered.

Most of these studies, nonetheless, have evinced an analytical proclivity to expound a particular set of international phenomena observable in non-Western contexts with a particular native concept or a set of native concepts, forging an exclusive and immutable semantic affiliation between the concept and what it signifies. For example, in the Chinese context, two indigenous concepts, tianxia and harmony, have been cultivated by Chinese scholars in a quite elaborate manner to exclusively explain China's understanding and associated practice of international relations. ${ }^{57}$ Transmuting conceptual indigeneity into conceptional idiosyncrasy, this insular practice of homegrown theorizing, called conceptual exclusivity here, can incur manifold degenerative shortcomings. First, it can readily reproduce the intellectual tendency of formulating analytical propositions only to constitute seemingly neutral and objective theoretical foundations for the promotion of parochial and subjective interests, both ideational and material, of the agents of theorizing, effectively retrogressing to problem-solving theorizing. It is argued, for example, that demonstrating "how non-Western alternatives [to the Westphalian system] can be even more state-centric," the reconceptualization of tianxia by Chinese scholars "presents a popular example of a new hegemony where imperial China's hierarchical governance is up-dated for the twenty-first century". ${ }^{58}$

Second, in the pursuit of theoretical pluralism, conceptual exclusivity would culminate in theoretical particularism, which, in turn, would stimulate theoretical exceptionalism, treating each non-Western context singularly. As an example, one of the three components of contemporary Chinese exceptionalism, according to Feng Zhang, is harmonious inclusionism, which "can be most effectively examined by tracing three recent discourses in China's intellectual circles: the application of the ancient idea of 'harmony with difference' (he er butong), the ongoing official discourse on the 'harmonious world' (hexie shijie), and the popular 'neoTianxiaism' (xin tianxia zhuyi)". ${ }^{59}$ The irony here is that the indigenous concepts of harmony

Pacific 11, no. 1 (2011): 16.

56 See, for example, Arlene B. Tickner and Ole Waever, eds., International Relations Scholarship around the World (Oxon: Routledge, 2009); Rosa Vasilaki, "Provincialising IR? Deadlocks and Prospects in Post-Western IR Theory," Millennium: Journal of International Studies 41, no. 1 (2012): 3-22.

57 For examples of the conceptual cultivations of tianxia and harmony by Chinese scholars, and their critique from different perspectives, see, William A. Callahan, "Chinese Visions of World Order: Post-Hegemonic or a New Hegemony?" International Studies Review 10 (2008): 749-61; Allen Carlson, "Moving Beyond Sovereignty? A Brief Consideration of Recent Changes in China's Approach to International Order and the Emergence of the Tianxia Concept," Journal of Contemporary China 20, no. 68 (2011): 89-102; Feng Zhang, "The Rise of Chinese Exceptionalism in International Relations," European Journal of International Relations 19, no. 2 (2011): 305-28; Chih-yu Shih, Sinicizing International Relations: Self, Civilization, Intellectual Politics in Subaltern East Asia (New York: Palgrave Macmillan, 2003); Nele Noesselt, "Mapping the World from a Chinese Perspective? The Debate on Constructing an IR Theory with Chinese Characteristics," in Constructing a Chinese School of International Relations: Ongoing Debates and Sociological Realities, ed. Yongjin Zhang and Teng-chi Chang (Oxon: Routledge, 2016), 98-112. For the concept of guanxi, see, for example, Emilian Kavalski, "Guanxi and Relational International Relations," (paper presented at the $2^{\text {nd }}$ All Azimuth Widening The World of IR Theorizing Workshop, Ankara, Turkey, September 23-24, 2016). In another study, Chihyu Shih discusses the concepts of nothingness, worlding, and balance of relationships to explain the foreign policy outlooks of Japan, Taiwan, and China respectively. Chih-yu Shih, "Transforming Hegemonic International Relations Theorization: Nothingness, Worlding, and Balance of Relationships," (paper presented at the $2^{\text {nd }}$ All Azimuth Widening The World of IR Theorizing Workshop, Ankara, Turkey, September 23-24, 2016).

58 Callahan, "Chinese Visions," 759.

59 Zhang, "The Rise of Chinese," 312. The other two components are great power reformism and benevolent pacifism. See, 
and tianxia are cultivated by Chinese scholars only to postulate the exceptional character of China's vision, and thus practice, of international relations. Theoretical particularism predicated on the exclusive semantic association of certain indigenous concepts with certain indigenous practices is liable to theoretical, and practical, exceptionalism. Furthermore, exceptionalism predicated on conceptual exclusivity is bound to constrain the receptivity of homegrown theoretical perspectives in other non-Western contexts in both theoretical premises and practical implications.

Third, in the quest to transcend West-centrism of IR theorizing, indigenous conceptual exclusivity becomes susceptible to duplicating the elemental dichotomous reasoning arguably underlying Western theorizing, albeit in native forms of dichotomies. As an example, again from the Chinese context, it is asserted that "if modern Western cosmopolitanism is an important ideological source of Western IR, traditional Chinese cosmopolitanism embodied in the tianxia system is a vital force shaping the way Chinese people think about IR." 60 As opposed to Western cosmopolitanism whose "simple and abstract assumptions" conceal "selfish national interests under the slogan of "universal good'," the advocates of Chinese cosmopolitanism argue that Chinese cosmopolitanism "takes 'tianxia' (the whole world) as an indivisible public domain and considers the world's problems in the context of the whole world, enabling Chinese thinking to go past national interests for the interest, value and responsibilities of this world as a whole in the long-term." ${ }_{61}$ Accordingly, they claim that Chinese cosmopolitanism "is inclusive, and favors culture over force, and free-choice over coercion." ${ }^{\prime \prime 2}$ The irony here is that one of the most universal concepts of IR theorizing, that is, cosmopolitanism, is redefined with indigenous attributes only to advance a dichotomy comprised of two cosmopolitanisms with ethnocentric connotations.

To avoid the above shortcomings, indigenous theoretical approaches in international relations can be propounded in congruence with different ways of conceptual cultivation. In this research, the second way of conceptual cultivation is adopted, which refers to redefining a concept already in use in Western theorizing by virtue of imparting indigenous properties to it. On the other hand, temporal and spatial embeddedness of theorizing in international relations is in fact compellingly argued. The proverbial articulation of this position is perhaps Robert W. Cox's assertion that "theory is always for someone and for some purpose." 63 Nonetheless, such embeddedness is not antithetical to the temporal and spatial omnipresence of the phenomena that is being theorized. Even though concepts and their attributes are fashioned indigenously, and display temporal and spatial subjectivity, the phenomena they signify can be in objective existence in a broad temporal and spatial spectrum, such as conflict and cooperation. The seeming discrepancy between objective phenomena and subjective concept delivers an analytical space, which is imperative to surmount the prohibitive semantic inflexibility of conceptual exclusivity in homegrown theorizing. For example, influence acts are not confined to certain temporal and spatial domains. Insofar as there are actors trying to affect the decisions of others, there are influence acts, and if they succeed, influence.

\footnotetext{
60 Wang Yiwei and Han Xueqing, "Why is There No Chinese IR Theory? A Cultural Perspective," in Constructing a Chinese School of International Relations: Ongoing Debates and Sociological Realities, ed. Yongjin Zhang and Teng-chi Chang (Oxon: Routledge, 2016), 62.

61 Yiwei and Xueqing, "Why is There No Chinese IR Theory?," 62.

62 Yiwei and Xueqing, "Why is There No Chinese IR Theory?," 62. Emphasis in original.

63 Robert W. Cox, "Social Forces, States and World Orders: Beyond International Relations Theory," Millennium: Journal of International Studies 10, no. 2 (1981): 128. Emphasis in original. To Cox, "all theories have a perspective," and "perspectives derive from a position in time and space, specifically social and political time and space." See, Cox, "Social Forces".
} 
Furthermore, influence acts can still reveal temporal and spatial variations with reference to different criteria, such as the actors involved, and the means employed, which enables the indigenous theorizing of influence with authentic attributes in discrete non-Western contexts.

\section{Conclusion}

The analytical departure point for homegrown theorizing is conceptual inquiries. Drawing on different indigenous conceptual resources, conceptual cultivation for homegrown theorizing can be performed in a number of ways. Indeed, incipient studies advancing homegrown theoretical perspectives predicated on authentic conceptual cultivations have been put forth for various non-Western contexts. Notwithstanding, in most of these studies, an analytical proclivity to expound a particular set of international phenomena observable in non-Western contexts with a particular native concept, forging an exclusive and immutable semantic affiliation between the concept and what it signifies, is noticeable. Conceptual exclusivity, as it is called here, can culminate in prohibitive semantic inflexibility potentially frustrating the progress in homegrown theorizing. A conceptual cultivation of influence is articulated here to provide further homegrown theoretical approaches with a framework which is potentially less prone to such exclusivity. Conceptual cultivation of influence transcends conceptual exclusivity by way of establishing an analytical framework which can be local in conceptual view and, at the same time, universal in theoretical purview.

By virtue of a variety of parameters transforming global governance structures in contemporary international relations, peoples and states of the non-West are no longer just quiescent objects of influence acts, and are incrementally evolving into assertive subjects of influence acts. Most IR theorists, it was once argued, "believe that studying the Western experience alone is empirically sufficient to establish general laws of individual, group, or state behavior irrespective of the point in time or the geographical location," and "few look to the Third World to seek evidence for their arguments." ${ }^{4}$ The conviction seems to persist. However, challenging this conviction on theoretical grounds has implications beyond theory inasmuch as influence is existentially consequential for non-Western societies and states. Conceptual cultivation of influence in non-Western contexts with authentic qualities is of critical analytical utility to inquire into the varying dynamics, forms, and outcomes of influence acts for specific non-Western contexts. It has equal analytical value to investigate asymmetrical influence structures in international relations repeatedly proved to be eviscerating for non-Western societies and states. Besides, influence acts are equally operational in interactions among non-Western contexts, which expands the scope of the relational variations of influence acts, simultaneously requiring and enabling indigenous conceptual cultivations of influence.

\section{Bibliography}

Abdelkader, Deina, Nassef Manabilang Adiong, and Raffaele Mauriello, eds. Islam and International Relations: Contributions to Theory and Practice. Hampshire: Palgrave Macmillan, 2016.

Acharya, Amitav. "Dialogue and Discovery: In Search of International Relations Theories beyond the West." Millennium: Journal of International Studies 39, no. 3 (2011): 619-37.

${ }^{64}$ Stephanie G. Neuman, "International Relations Theory and the Third World: An Oxymoron?" in International Relations Theory and the Third World, ed. Stephanie G. Neuman (New York: St. Martin's Press, 1998), 2. In addition, to Neuman, "even central concepts [in IR theory] such as anarchy, the state, sovereignty, rational choice, alliance, and the international system are troublesome 
Acharya, Amitav, and Barry Buzan. "Why is There No Non-Western International Relations Theory? An Introduction." In Non-Western International Relations Theory: Perspectives on and beyond Asia, edited by Amitav Acharya and Barry Buzan, 1-25. Oxon: Routledge, 2010.

Aron, Raymond. Peace and War: A Theory of International Relations. New York: Frederick A. Praeger, 1968.

Aydınl, Ersel, and Julie Mathews. "Periphery Theorising for a Truly Internationalised Discipline: Spinning IR Theory out of Anatolia.” Review of International Studies 34 (2008): 693-712.

Ayoob, Muhammed. "Inequality and Theorizing in International Relations: The Case for Subaltern Realism." International Studies Review 4, no. 3 (2002): 27-48.

Baldwin, David A. "The Concept of Security.” Review of International Studies 23, no. 1 (1997): 5-26.

. "Power Analysis and World Politics: New Trends versus Old Tendencies." World Politics 31, no. 2 (1979): 161-94.

Biltekin, Gonca. "Özgün teori inşasi ve bati-dişi uluslararasi ilişkiler teorileri [Homegrown theorizing and nonwestern international relations theories]." In Uluslararası ilişkiler teorileri [International relations theories], edited by Ramazan Gözen, 517-64. İstanbul: İletişim Yayıncılık, 2014.

Briggs, Asa, and Patricia Clavin. Modern Europe, 1789-Present. Oxon: Routledge, 2013.

Boening, Astrid et al., eds. Global Power Europe-Vol. 2: Policies, Actions, and Influence of the EU's External Relations. Heidelberg: Springer, 2013.

Booth, Ken. Theory of World Security (Cambridge: Cambridge University Press, 2007).

Buzan, Barry. People, States, and Fear: The National Security Problem in International Problems. Sussex: Wheatsheaf Books, 1983.

Buzan, Barry, and Lene Hansen. The Evolution of International Security Studies. Cambridge: Cambridge University Press, 2009.

Caballero-Anthony, Mely, Ralf Emmers, and Amitav Acharya, eds. Non-Traditional Security in Asia: Dilemmas in Securitisation. Oxon: Routledge, 2016.

Callahan, William A. "Chinese Visions of World Order: Post-Hegemonic or a New Hegemony?" International Studies Review 10 (2008): 749-61.

Carlson, Allen. "Moving Beyond Sovereignty? A Brief Consideration of Recent Changes in China's Approach to International Order and the Emergence of the Tianxia Concept." Journal of Contemporary China 20, no. 68 (2011): 89-102.

Chaulia, Sreeram S. "BJP, India's Foreign Policy and the 'Realist Alternative' to the Nehruvian Tradition." International Politics 39, no. 2 (2002): 215-34.

Chen, Ching-Chang. "The Absence of Non-Western IR Theory in Asia Reconsidered." International Relations of the Asia-Pacific 11, no. 1 (2011): 1-23.

Collins, Alan, ed. Contemporary Security Studies. Oxford: Oxford University Press, 2013.

Cox, Robert W. "Social Forces, States and World Orders: Beyond International Relations Theory." Millennium: Journal of International Studies 10, no. 2 (1981): 126-55.

de Lange, Deborah E. Power and Influence: The Embeddedness of Nations. New York: Palgrave Macmillan, 2010.

Dowding, Keith, ed. Encyclopedia of Power. California: SAGE, 2011.

Fawn, Rick. "Alliance Behavior, the Absentee Liberator and the Influence of Soft Power: Post-communist State Positions over the Iraq War in 2003." Cambridge Review of International Relations 19, no. 3 (2006): 465-80.

Fierke, Karin M. Critical Approaches to International Security. Cambridge: Polity Press, 2015.

Forest, James J. F., ed. Influence Warfare: How Terrorists and Governments Fight to Shape Perceptions in a War of Ideas. Westport: Praeger Security International, 2009.

Forsberg, Tuomas, and Antti Seppo. "Power without Influence? The EU and Trade Disputed with Russia." EuropeAsia Studies 61, no. 10 (2009): 1805-23.

Freedman, Amy. "Rice Security in Southeast Asia: Beggar Thy Neighbor or Cooperation." The Pacific Review 26, no. 5 (2013): 433-54 
Gardner, Lloyd C. Spheres of Influence: The Great Powers Partition Europe, from Munich to Yalta. Chicago: Ivan R. Dee, 1993.

Gautam, P. K. "Relevance of Kautilya's Arhasastra." Strategic Analysis 37, no. 1 (2013): 21-8.

Gerring, John. "What Makes a Concept Good? A Critical Framework for Understanding Concept Formation in the

Social Sciences." Polity 31 (1999): 357-93.

Goertz, Gary. Social Science Concepts: A User's Guide. New Jersey: Princeton University Press, 2006.

Goh, Evelyn. "Great Powers and Hierarchical Order in Southeast Asia: Analyzing Regional Security Strategies." International Security 32, no. 3 (2007-08): 113-57.

Halperin, Sandra. "International Relations Theory and the Hegemony of Western Conceptions of Modernity."

In Decolonizing International Relations, edited by Branwen Gruffydd Jones, 43-63. Maryland: Rowman \& Littlefield Publishers, 2006.

Hart, Jeffrey. "Three Approaches to the Measurement of Power in International Relations." International Organization 30, no. 2 (1976): 289-305.

Hartmann, Frederick H. The Relations of Nations. New York: The Macmillan Company, 1969.

Hast, Susanna. Spheres of Influence in International Relations: History, Theory and Politics. Surrey: Ashgate, 2014.

Henderson, Errol A. "Hidden in Plain Sight: Racism in International Relations Theory." Cambridge Review of International Relations 26, no. 1 (2013): 71-92.

Hobson, John M. "Is Critical Theory Always for the White West and for Western Imperialism? Beyond Westphalian towards a Post-racist Critical IR.” Review of International Studies 33 (2007): 91-116.

Hough, Peter et al., eds. International Security Studies: Theory and Practice. Oxon: Routledge, 2015.

Hui, Victoria Tin-bor. War and State Formation in Ancient China and Early Modern Europe.Cambridge: Cambridge University Press, 2005.

Hunter, Robert E. Integrating Instruments of Power and Influence: Lessons Learned and Best Practices. Santa Monica: RAND, 2008.

Kaarbo, Juliet. "Power and Influence in Foreign Policy Decision Making: The Role of Junior Coalition Partners in German and Israeli Foreign Policy.” International Studies Quarterly 40, no. 4 (1996): 501-30.

Kalpakian, Jack. "Ibn Khaldun's Influence on Current International Relations Theory." The Journal of North African Studies 13, no. 3 (2008): 363-76.

Kamel, Lorenzo. Imperial Perceptions of Palestine: British Influence and Power in Late Ottoman Times. New York: I. B. Tauris, 2015.

Kang, David C. "Hierarchy and Legitimacy in International Systems: The Tribute System in Early Modern East Asia.” Security Studies 19, no. 4 (2010): 591-622.

Kavalski, Emilian. "Guanxi and Relational International Relations." Paper presented at the 2nd All Azimuth Widening The World of IR Theorizing Workshop, Ankara, Turkey, September 23-24, 2016.

Kautilya. The Arthashastra. New Delhi: Penguin Books, 1992.

Kayaoglu, Turan. "Westphalian Eurocentrism in International Relations Theory." International Studies Review 12 (2010): 193-217.

Kinnvall, Catarin. Globalization and Religious Nationalism in India: The Search for Ontological Security. Oxon: Routledge, 2006.

Kousoulas, Dimitrios G. Power and Influence: An Introduction to International Relations. Monterey: Wadsworth Publishing, 1985.

Mahan, Alfred Thayer. Influence of Sea Power upon History, 1660-1783. Boston: Little, Brown and Co., 1918.

Mahnken, Thomas G., and Dan Blumenthal, eds. Strategy in Asia: The Past, Present, and Future of Regional Security. Stanford: Stanford University Press, 2014.

Malik, Ahmed Ijaz. US Foreign Policy and the Gulf Wars: Decision Making and International Relations. London: I. B. Tauris, 2015.

Mckale, Donald M. "Influence without Power: The Last Khedive of Egypt and the Great Powers, 1914-1918." 
Middle Eastern Studies 33, no. 1 (1997): 20-39.

Mearsheimer, John J. The Tragedy of Great Power Politics. New York: W. W. Norton \& Company, 2001.

Miller, Benjamin. “The Concept of Security: Should it be Redefined?” Journal of Strategic Studies 24, no. 2 (2001): 13-42.

Mitzen, Jennifer. "Ontological Security in World Politics: State Identity and the Security Dilemma." European Journal of International Relations 12, no. 3 (2006): 341-70.

Monroe, Alice V., ed. China's Foreign Policy and Soft Power Influence. New York: Nova Science Publishers, 2010. Neuman, Stephanie G. "International Relations Theory and the Third World: An Oxymoron?" In International Relations Theory and the Third World, edited by Stephanie G. Neuman, 1-30. New York: St. Martin's Press, 1998.

Noesselt, Nele. "Mapping the World from a Chinese Perspective? The Debate on Constructing an IR Theory with Chinese Characteristics." In Constructing a Chinese School of International Relations: Ongoing Debates and Sociological Realities, edited by Yongjin Zhang and Teng-chi Chang, 98-112. Oxon: Routledge, 2016.

Norwitz, Jeffrey H., ed. Pirates, Terrorists, and Warlords: The History, Influence, and Future of Armed Groups around the World. New York: Skyhorse Publishing, 2009.

Nye, Jr., Joseph S. The Paradox of American Power: Why the World's Only Superpower Can't Go it Alone. New York: Oxford University Press, 2002.

- Power in the Global Information Age: From Realism to Globalization. Oxon: Routledge, 2004.

Pansardi, Pamela. "Power to and Power over: Two Distinct Concepts of Power." Journal of Political Power 5, no. 1 (2012): 73-89.

Petersen, Tore T. Anglo-American Policy toward the Persian Gulf, 1978-1985: Power, Influence, and Restraint. Eastbourne: Sussex University Press, 2015.

Phillips, Ann L. Power and Influence after the Cold War: Germany in East Central Europe. Lanham: Rowman and Littlefield, 2000.

Podliska, Bradley F. Acting Alone: A Scientific Study of American Hegemony and Unilateral Use-of-Force Decision Making. Plymouth: Lexington Books, 2010.

Pourmokhtari, Navid. "A Postcolonial Critique of State Sovereignty in IR: The Contradictory Legacy of a 'Westcentric' Discipline.” Third World Quarterly 34, no. 10 (2013): 1767-93.

Pressman, Jeremy. "Power without Influence: The Bush Administration's Foreign Policy Failure in the Middle East.” International Security 33, no. 4 (2009): 149-79.

Rana, Aspy P. The Imperatives of Nonalignment: A Conceptual Study of India 's Foreign Policy Strategy in the Nehru Period. Delhi: Macmillan, 1976.

Ripsman, Norrin M., and T. V. Paul. Globalization and the National Security State. New York: Oxford University Press, 2010

Roe, Paul. Ethnic Violence and the Societal Security Dilemma. Oxon: Routledge, 2005.

Rotberg, Robert I., ed. China into Africa: Trade, Aid, and Influence. Baltimore: Brookings Institution Press, 2008.

Rothgeb, John M. Defining Power: Influence \& Force in the Contemporary International System. New York: St. Martin's Press, 1993.

Salaman, Redcliffe. The History and Social Influence of the Potato. Cambridge: Cambridge University Press, 1985. Schelling, Thomas C. Arms and Influence. New Haven: Yale University Press, 2008.

Schrogl, Kai-Uwe et al., eds. Handbook of Space Security: Policies, Applications and Programs. New York: Springer, 2015.

Schweller, Randall L. Unanswered Threats: Political Constraints on the Balance of Power. New Jersey: Princeton University Press, 2008.

Shih, Chih-yu. Sinicizing International Relations: Self, Civilization, Intellectual Politics in Subaltern East Asia. New York: Palgrave Macmillan, 2003.

“Transforming Hegemonic International Relations Theorization: Nothingness, Worlding, and Balance of 
Relationships." Paper presented at the $2^{\text {nd }}$ All Azimuth Widening the World of IR Theorizing Workshop, Ankara, Turkey, September 23-24, 2016.

Steele, Brent J. Ontological Security in International Relations: Self-Identity and the IR State. Oxon: Routledge, 2008.

Sullivan III, Michael J. American Adventurism Abroad:30 Invasions, Interventions, and Regime Changes since World War II. Westport: Praeger, 2004.

Tadjbakhsh, Shahrbanou, and Anuradha Chenoy. Human Security: Concepts and Implications. Oxon: Routledge, 2007.

Tickner, Arlene B. “Core, Periphery and (Neo)Imperialist International Relations.” European Journal of International Relations 19, no. 3 (2013): 627-46.

Tickner, Arlene B., and Ole Waever, eds. International Relations Scholarship around the World. Oxon: Routledge, 2009.

Tsilipakos, Leonidas. Clarity and Confusion in Social Theory: Taking Concepts Seriously. Surrey: Ashgate Publishing, 2015.

Turton, Helen Louise. International Relations and American Dominance: A Diverse Discipline. Oxon: Routledge, 2016.

Ungerer, Carr. "Influence without Power: Middle Powers and Arms Control Diplomacy during the Cold War." Diplomacy and Statecraft 18, no. 2 (2007): 393-414.

Vasilaki, Rosa. "Provincialising IR? Deadlocks and Prospects in Post-Western IR Theory." Millennium: Journal of International Studies 41, no. 1 (2012): 3-22.

Viotti, Paul R., and Mark V. Kauppi. International Relations Theory: Realism, Pluralism, Globalism, and Beyond. Needham Heights: Allyn \& Bacon, 1999.

Vreeland, James Raymond, and Axel Dreher. The Political Economy of the United Nations Security Council: Money and Influence. New York: Cambridge University Press, 2014.

Wagemakers, Joas. A Quietist Jihadi: The Ideology and Influence of Abu Muhammad al-Maqdisi. New York: Cambridge University Press, 2012.

Waltz, Kenneth N. Theory of International Politics. Long Grove: Waveland Press, 2010.

Wang, Cho-yun Yuan-Kang. Harmony and War: Confucian Culture and Chinese Power Politics. New York: Columbia University Press, 2011.

Warleigh, Alex, and Jenny Fairbrass, eds. Influence and Interests in the European Union: The New Politics of Persuasion and Advocacy. London: Europa Publications, 2002.

Williams, Paul D., ed. Security Studies: An Introduction. Oxon: Routledge, 2013.

Xuetong, Yan. Ancient Chinese Thought, Modern Chinese Power. New Jersey: Princeton University Press, 2011.

— .Xun Zi’s [Sun Tzu] Thoughts on International Politics and Their Implications." Chinese Journal of International Politics 2, no. 1 (2008): 135-65.

Yiwei, Wang, and Han Xueqing. "Why is There No Chinese IR Theory? A Cultural Perspective." In Constructing a Chinese School of International Relations: Ongoing Debates and Sociological Realities, edited by Yongjin Zhang and Teng-chi Chang, 52-67. Oxon: Routledge, 2016.

Zimmerling, Ruth. Influence and Power: Variations on a Messy Theme. Dordrecht: Springer, 2005.

Zhang, Feng. "Confucian Foreign Policy Traditions in Chinese History." The Chinese Journal of International Politics 8, no. 2 (2015): 197-218.

- "The Rise of Chinese Exceptionalism in International Relations." European Journal of International Relations 19, no. 2 (2011): 305-28. 